\title{
PUBLIC RELATIONS 2.0 NA PRZYKLADZIE ANALIZY PROFILI BIBLIOTEK UNIWERSYTECKICH NA PORTALU SPOŁECZNOŚCIOWYM FACEBOOK
}

\begin{abstract}
The communications revolution implemented by social media has also influenced on public relations in libraries. Academic libraries, identified mainly with information and scientific activity, considered some new communications requirements of a user and the intercourses with environment via Facebook social network. How did the choice of communications tools 2.0 influence the relations with environment and the image of discussed libraries? In order to obtain an answer, the author of the article analysed tools and contents used by university libraries profiles on Facebook. The analysis was supplemented with the description of the interview's results, conducted with administrators of university libraries' profiles on Facebook.
\end{abstract}

Słowa kluczowe: Public Relations, wizer unek, Facebook, biblioteka, social media, komunikacja

\section{Wstęp}

Budowanie wizerunku instytucji w XXI w. tylko za pomocą mediów tradycyjnych staje się już niewystarczające, wręcz błędne, a w opinii odbiorców niewiarygodne ${ }^{1}$. Dlatego niezwykle ważne jest, aby wykorzystać potencjalne możliwości tkwiące w e-społeczeństwie podczas planowania działań public relations w Internecie. Biblioteki akademickie, zazwyczaj utożsamiane z działalnością informacyjną i naukową, uwzględniły nowe wymagania komunikacyjne użytkownika i tworzą swoje profile w popularnych mediach społecznościowych typu Facebook. W jaki sposób administratorzy profili bibliotek planują kontakt z otoczeniem i jak z użyciem tego narzędzia kształtują wizerunek omawianych bibliotek? Czy mniej oficjalny kanał komunikacji to dobry wybór bibliotek uniwersyteckich na kształtowanie wizerunku w wersji 2.0?

\footnotetext{
${ }^{1}$ A. Werenowska, E. Jaska, Nowoczesne narzędzia public relations $w$ ksztaltowaniu wizerunku przedsiębiorstwa, [w:] Public relations - nie tylko Facebook, red. K. Stasiuk-Krajewska, Z. Chmielewski, D. Tworzydło, Rzeszów 2013, s. 169.
} 


\section{Klasyczne definicje public relations (PR)}

Powszechnie uważa się, że pojęcie public relations we współczesnym rozumieniu wykształciło się dopiero w XX w. Za twórcę nowoczesnego PR uważany jest amerykański dziennikarz Ivy Ledbetter Lee, autor creda wielu późniejszych agencji PR, które brzmi: „,mów prawdę o działaniach organizacji, nawet wówczas, gdy z tego powodu dozna szkód"2. Dla Lee warunkiem akceptacji i zrozumienia organizacji były sformowane na początku XX w. poglądy, iż społeczeństwa nie należy lekceważyć, natomiast społeczeństwo należy informować ${ }^{3}$. W latach trzydziestych i czterdziestych XX w. amerykańskie doświadczenia w dziedzinie PR dotarły również do Europy. W pierwszej kolejności do Wielkiej Brytanii, następnie do Niemiec i Francji ${ }^{4}$. W Polsce pierwsze firmy PR powstały na początku lat dziewięćdziesiątych XX w. ${ }^{5}$

Określenie public relations stało się terminem międzynarodowym, dlatego też polskie odpowiedniki „stosunki społeczne”, „stosunki publiczne” czy „imagistyka społeczna" ${ }^{6}$ nie oddają istoty omawianego zjawiska. W literaturze przedmiotu oraz występuje wiele definicji. Według badaczy PR to między innymi:

- $\quad$ planowe i nieustanne dążenie do stworzenia dobrej reputacji firmy i zrozumienia między instytucją i jej odbiorcami ${ }^{7}$;

- narzędzie zintegrowanego komunikowania marketingowego, dotyczy relacji wewnątrz firmy i relacji firmy z jej otoczeniem zewnętrznym ${ }^{8}$;

- $\quad$ funkcja zarządzania, która ocenia nastawienie społeczne, ustala kierunki działania i sposób postępowania osoby fizycznej lub prawnej (firmy) zgodnie z interesem społecznym oraz realizuje program działań $\mathrm{w}$ celu uzyskania społecznego zrozumienia i akceptacji';

\footnotetext{
${ }^{2}$ K. Wójcik, Public Relation: od A do Z., Warszawa 2001, s. 157, 159.

${ }^{3}$ Public Relations, red. J. Olędzki, D. Tworzydło, Warszawa 2008, s. 19-20.

${ }^{4}$ K. Wójcik, op. cit., s. $165-168$.
}

${ }^{5}$ W 1995 roku powstało Polskie Stowarzyszenie Public Relations, którego głównym celem jest upowszechnienie działań PR w kręgach biznesu i opinii publicznej oraz praca nad profesjonalizmem usług. Patrz w: J. Krawulski, Public Relations: wybrane zagadnienia, Poznań 2001, s. 14-15.

${ }^{6}$ D. Piontek, Imagistyka społeczna czy marketing polityczny, [w:] Media masowe $w$ systemach demokratycznych, red. B. Dobek-Ostrowska, Wrocław 2003, s. 115.

${ }^{7}$ S. Black, Public Relations, Warszawa 1998, s. 15.

${ }^{8} \mathrm{R}$. Mayer, Jak wygrać każde negocjacje nie podnoszac glosu, nie tracac zimnej krwi i nie wybuchajac gniewem, Warszawa 2007, s. 207.

${ }^{9}$ E. M. Cenker, Public relations, Poznań 2007, s. 15. 
- działania promocyjne, których celem jest stworzenie i utrzymywanie zaufania do przedsiębiorstwa $\mathrm{w}$ otoczeniu, $\mathrm{w}$ jakim ono funkcjonuje $\mathrm{e}^{10}$;

- uczciwa i obiektywna, fachowa i kompetentna, pełna i szybka, przyjazna i odpowiedzialna informacja ${ }^{11}$.

Każda z powyższych definicji oddaje w jakimś zakresie sedno działań budujących relacje z klientem. Na uwagę zasługuje często cytowana deklaracja meksykańska będąca owocem spotkania praktyków reprezentujących stowarzyszenia PR z 31 krajów, które odbyło się w Meksyku w 1978 r. Brzmi ona następująco: „Działalność public relations jest dziedziną sztuki i nauką społeczną polegającą na analizowaniu tendencji, przewidywaniu ich konsekwencji, doradzaniu przywódcom organizacji oraz realizowaniu zaplanowanych programów działań służących zarówno interesom owych organizacji, jak i interesowi publicznemu"12. Rolę współpracy podkreślała definicja Amerykańskiego Stowarzyszenia Public Relations (The Public Relations Society of America), zaś Brytyjski Instytut Public Relations (Institute of Public Relations) dołączył do pojęcia zagadnienie troski o reputację.

Mimo wielu definicji istotą PR pozostaje niezmiennie nawiązanie relacji (czy to ze środowiskiem zewnętrznym czy wewnętrznym), powstałych w wyniku zaplanowanej i skutecznej komunikacji, nawiązanej w celu rozpowszechniania pozytywnego wizerunku oraz podwyższenia reputacji danej organizacji.

\section{Budowanie nowych relacji w sieci, czyli PR 2.0}

Współczesne społeczeństwo preferuje samodzielne poszukiwania interesujących je informacji i to w dogodnym dla siebie czasie i miejscu. Uczniowie szkół średnich i studenci to obecnie przedstawiciele Pokolenia XD, czyli cyfrowo świadomych dzieci rodziców z Pokolenia X, które urodziły się między 1995 i 2001 rokiem. Reprezentant tego pokolenia nie potrafi wyobrazić sobie świata bez Internetu czy wszechobecnej cyfryzacji ${ }^{13}$. Jak pokazały wyniki badania przeprowadzonego w przez Taylor Nelson Sofres w 2009 r., aż 95\% młodych ludzi czuło, że Internet i komputery są dla nich ważne, 53\% uważało, że

${ }^{10}$ K. Wanielista, I. Miłkowska, Słownik menadżera, Wrocław 1998, s. 207.

${ }^{11}$ A. Kadragic, P. Czarnowski, Public Relations, czyli promocja reputacji, Warszawa 1997, s. 8.

${ }^{12}$ A. Davis, Public relations, Warszawa 2007, s. 19-20.

${ }^{13}$ Pokolenie XD - nowe pokolenie świadomych cyfrowo dzieci, „PC FORMAT”, https:// www.pcformat.pl/News-Pokolenie-XD----nowe-pokolenie-swiadomych-cyfrowo-dzieci,n,4881u tm_source=paste\&utm_medium=paste\&utm_campaign=firefox, [dostęp: 10.07.2017]. 
Internet usprawniał ich życie, zaś dla 44\% Internet ułatwiał kontakt z przyjaciółmi ${ }^{14}$. Postrzeganie Internetu w ten sposób, szczególnie przez młodych ludzi, zapowiada wyraźną zmianę preferencji dzisiejszych i przyszłych konsumentów. Tę ewolucję komunikacji powinni uwzględnić w swej pracy także przedstawiciele świata marketingu, reklamy i public relations.

Funkcjonujący w Internecie trend Web 2.0 opiera się na mediach społecznościowych. Mobilne społeczeństwo potrzebuje narzędzi, które będą pokonywały jak najwięcej barier informacyjnych i w tym celu wykorzystuje nowe techniki: komunikatory, fora dyskusyjne, blogi czy czaty. Serwisy społecznościowe to obecnie główne media za pośrednictwem których ludzie angażują się w interakcje, a liczba ich użytkowników systematycznie się powiększa. Według raportu „We are social media” z 2017 r. na świecie jest już 3,77 mld użytkowników Internetu. To stanowi 50\% wszystkich ludzi na kuli ziemskiej. $\mathrm{Z}$ raportu wynika również, że $\mathrm{z}$ mediów społecznościowych korzysta ponad 2,80 mld osób, co oznacza, że w ciągu 2016 r. przybyło 482 mln nowych użytkowników. Zawężając rynek mediów społecznościowych do Polski wspomniany raport wykazuje, że w styczniu 2017 r. w Polsce odnotowano 27,92 mln użytkowników Internetu (67\% Polaków), z czego $15 \mathrm{mln}$ (39\%) aktywnie korzysta $\mathrm{z}$ mediów społecznościowych ${ }^{15}$. Do najpopularniejszych platform w Polsce w tym okresie, według rankingu „We are social media”, należały światowe potęgi takie jak You Tube, Facebook, Google +.

Obecny zasięg Internetu, technologia Web 2.0 połączona $\mathrm{z}$ chęcią budowania i udostępniania treści przez publiczność, przekształciła branżę PR oraz dotychczasowe metody prowadzenia działań marketingowych. Wśród nowych zwyczajów konsumenckich warto wymienić: redukowanie barier w dostępie do produktów i w uzyskiwaniu ich na własność z wykorzystaniem nowoczesnej technologii (usługi online), wzrost rangi blogów branżowych zastępujących czasopisma, przeglądanie oferty w Internecie (katalog online, wyszukiwarka), gromadzenie informacji o kliencie (statystyki biblioteczne).

Jerzy Olędzki, badacz zagadnienia PR, zwraca uwagę na następujące zagrożenia: „ludzie uodpornili się już na działania marketingowe, stali się mniej wrażliwi na coraz bardziej wymyślne chwyty i fortele promocyjne, fantazjowanie copywrighterów, cwaniactwo sprzedawców czy geszefty reklamowe"16.

${ }^{14}$ T.N. Sofres, Pokolenie XD, raport przeprowadzony na zlecenie The Walt Disney Company na grupie dzieci $w$ wieku 8-14 lat w sześciu krajach Europy: Wielka Brytania, Niemcy, Francja, Hiszpania, Włochy i Polska, 2009 r., za: K. Fabjaniak-Czerniak, Internetowe media społecznościowe jako narzędzie public relations, [w:] Zarządzanie w sytuacjach kryzysowej niepewności, red. K. Kubiak, Warszawa 2012, s. 173.

${ }^{15}$ Special Report: Digital in 2017: Global Overview, [w:] Wearesocial.com, https://weare social.com/special-reports/digital-in-2017-global-overview, [dostęp: 10.07.2017]. 
Niejaką odpowiedzią na tego typu kryzys działań PR-owych jest strategia marketingowa, polegająca na podejmowaniu odpowiednich zachowań, które umożliwią odbiorcom samodzielne odnalezienie nadawcy danego przekazu, czyli marketing przychodzący (inbound marketing) ${ }^{17}$. Relacje pobudzone za pomocą tej strategii stawiają odbiorcę produktu w aktywnej roli inicjatora relacji.

Idea PR 2.0 powstała długo przed narodzinami mediów społecznościowych, w latach dziewięćdziesiątych XX w. Jej teoretyk, Brian Solis, analizował między innymi zagadnienie łączenia PR, multimediów i serwisów WWW ${ }^{18}$. Specjaliści PR dodali zasoby Web 2.0 do budowania strategii marki i planowanie bardziej ukierunkowanej i skutecznej komunikacji internetowej. Zdaniem amerykańskiej badaczki PR, Deirdre K. Breakenridge, są trzy główne powody, dla których warto praktykować PR 2.0: dwustronna komunikacja, umożliwiająca bezpośrednią reakcję na opinię odbiorcy; łatwiejsze redakcje komunikatów (narzędzia Web 2.0 jako formy uczestnictwa w mediach) oraz dłuższa i silniejsza relacja $\mathrm{z}$ odbiorcą komunikatu ${ }^{19}$. Platformy mediów społecznościowych zwiększają moc społeczności - poprzez promocję głębokich relacji ułatwiają szybką organizację, propagują wiedzę oraz umożliwiają skuteczne filtrowanie informacji ${ }^{20}$.

\section{PR w bibliotekach}

Odnosząc pojęcie PR do biblioteki można stwierdzić, iż jego zadaniem jest stworzenie i utrzymanie jak najlepszego wizerunku biblioteki, jednoznacznie postrzeganego przez jej użytkowników, społeczność lokalną, władze, sponsorów i inne instytucje finansujące jej działanie ${ }^{21}$. Biblioteka spełnia w swoim otoczeniu określoną rolę społeczną i kulturotwórczą. Zaspokaja indywidualne

${ }^{16}$ J. Olędzki, Preambuła o PR między stużba organizacji i społeczeństwu, [w:] Public relations we wspótczesnym świecie: między stużba organizacji $i$ społeczeństwu, wybór i red. nauk. J. Olędzki, Warszawa 2011, s. 14.

${ }^{17}$ B. Hallingan, D. Shah, Inbound Marketing: daj się poznać w Google, serwisach spotecznościowych i na blogu, Gliwice 2010, s. 12.

${ }^{18}$ B. Solis, Engage!: The Complete Guide for Brands and Businesses to Build, Cultivate, and Measure Success in the New Web, New York 2010; idem, The End of Business as Usual: Rewire the Way You Work to Succeed in the Consumer Revolution, New York 2011.

${ }^{19}$ D.K. Breakenridge, PR 2.0: New Media, New Tools, New Audiences, New Jersey 2008, s. $17-18$.

${ }^{20}$ G.C. Kane, R.G. Fichman, J. Gallaugher, J. Glaser, Community relations 2.0, „Harvard Business Review” 2009, 01 Nov 87(11): 45-50, 132.

${ }^{21}$ M. Huczek, Public Relation a wizerunek biblioteki, „Biuletyn EBIB” 2004, nr 5, http:// ebib.oss.wroc.pl/2004/56/huczek.php, [dostęp 14.05.2017]. 
i wspólne potrzeby, wspomaga proces edukacji, a jednocześnie ma istotny wpływ na formowanie się postaw społecznych oraz wyobrażeń. Te z kolei warunkują stosunek do biblioteki rzeczywistych i potencjalnych użytkowników, a także osób i organizacji patronujących czy wspierających. Dlatego też nowoczesna książnica świadomie włącza elementy marketingu do swojej działalności w celu ustalenia misji, strategii oraz jej pożądanego wizerunku.

Termin PR w bibliotece pierwszy raz pojawia się w periodyku zawodowym „Bibliotekarz”. Elżbieta Budkiewicz i Renata Mroczek opisały tam działania aktywizujące pracę Biblioteki Akademii Wychowania Fizycznego, wspominając że „Niezaprzeczalna jest rola wystaw w zakresie public relations. Public relations jest zespołem celowo zorganizowanych działań zapewniających systematyczne komunikowanie się ze swoim otoczeniem, tworzenie pozytywnego rozgłosu i korzystnej dla biblioteki atmosfery"22.

$\mathrm{Z}$ analizy różnorodnych koncepcji PR wynika, że jego celem końcowym jest uzyskanie uwagi publicznej i stworzenie pozytywnego wizerunku biblioteki, w czego osiągnięciu może pomóc wypełnianie między innymi takich zadań jak:

- $\quad$ obiektywne i wszechstronne informowanie oraz edukowanie użytkowników;

- rozwijanie efektywnej komunikacji jedno- i dwukierunkowej;

- $\quad$ wpływanie na zachowania i postawy klientów;

- $\quad$ budowanie zaufania i klimatu dla akceptacji produktów bibliotecznych;

- $\quad$ kreowanie prestiżu i wizerunku biblioteki;

- $\quad$ wskazanie kierunku zmian i rozwoju biblioteki ${ }^{23}$.

Potencjał narzędzi Web 2.0 dostrzegli również bibliotekarze, którzy chętnie zaadaptowali je, aby zbudować zaangażowaną społeczność wokół danej organizacji. Interaktywna komunikacja mediów społecznościowych wpływa pośrednio na poprawę jakości usług bibliotecznych oraz wzbogacenie oferty kierowanej do użytkowników. Form i sposobów wykorzystania social mediów przez biblioteki jest bardzo wiele. Zdaniem Bożeny Jaskowskiej najlepiej w promowaniu usług bibliotecznych sprawdzają się takie narzędzia jak: profile

${ }^{22}$ E. Budkiewicz, R. Mroczek, Marketingowa rola wystaw - bibliotekarstwo aktywne, „Bibliotekarz” 1995, nr 11, s. 16.

${ }^{23} \mathrm{M}$. Dudziak-Kowalska, Internetowe strony $W W W$ bibliotek jako element public relations, „Biuletyn EBIB” 2004, nr 5, http:bib.oss.wroc.pl/2004/56/kowalska.php, [dostęp: 19.05. 2017]. 
w najpopularniejszych serwisach społecznościowych (wraz z dodatkowymi aplikacjami), serwisy wideo wzbogacające tradycyjny przekaz o element multimediów, mikroblogi oraz blog biblioteczny ${ }^{24}$.

Badacze mediów społecznościowych w bibliotekach, Samuel Kai-Wah Chu i Helen S. Du wytypowali najczęstsze motywy wykorzystywania zasobów online przez te instytucje. Należą do nich: informowanie na temat zbiorów i usług bibliotecznych, w tym e-zasobów oraz wydarzeń, jakie dzieją się w bibliotece, tworzenie grup dyskusyjnych oraz zapytań do bibliotekarza ${ }^{25}$.

Główne powody angażowania się bibliotek w relacje budowane $\mathrm{w}$ mediach społecznościowych to między innymi zwiększenie własnej widoczności, unowocześnianie wizerunku, poprawianie e-reputacji, dystrybucja informacji, promocja zbiorów, programów i usług, zwiększenie oddziaływania, zacieśnienie relacji z użytkownikami, budowa sieci współpracy, pozyskanie nowych klientów ${ }^{26}$.

\section{Facebook jako narzędzie PR 2.0}

Funkcjonowanie sieci społecznościowych oparte jest na budowaniu własnych profili przez aktywnych użytkowników. Osoba lub instytucja posiadająca konto na danym serwisie może umieszczać na nim różnego rodzaju informacje, zdjęcia, filmy oraz linki do stron, które lubi lub chce rozpowszechnić. Podstawą działania social mediów jest możliwość komunikowania się z innymi użytkownikami, którą zapewnia wewnętrzna skrzynka wiadomości (wewnętrzna poczta) czy wbudowany w środowisko danego serwisu komunikator (na przykład Facebook Messenger) lub czat. Oprócz funkcji komunikacyjnej istotna jest również marketingowa, w której media społecznościowe stanowią skuteczne narzędzie do autoprezentacji ${ }^{27}$. Marketing w mediach społecznościowych przyjmuje formę przyspieszonego marketingu wirusowego udostępnianego przez internautów z profilu na profil ${ }^{28}$.

${ }^{24}$ B. Jaskowska, Bądźmy tam, gdzie oni! Elementy social media marketingu $w$ bibliotece, [w:] Bibliotekarze bez bibliotek, czyli bibliotekarstwo uczestniczace, Białystok 2012, s. 298.

${ }^{25}$ S. Kai-Wah Chu, H.S. Du, Social networking tools for academic libraries, „Journal of Librarianship and Information Science" 2013, no 45 (1), s. 70.

${ }^{26}$ L. Luo, Y. Wang, L. Han, Marketing via social media: a case study, „Library Hi Tech” 2013, vol. 31, no 3, s. 455-466.

${ }^{27}$ A. Miotk, Skuteczne social media. Prowadź działania, osiagaj zamierzone efekty. Gliwice 2013, s. 32; M. Kotyśko, P. Izdebski, M. Michalak, P. Andryszak, A. Pluto-Prądzińska, Nadmierne korzystanie z sieci społecznościowych, „Alkoholizm i Narkomania” 2014, t. 27, nr 2, s. $177-197$.

${ }^{28}$ D. Barefoot, J. Szabo, Znajomi na wage złota, Warszawa 2014, s. 29. 
Specjaliści PR znajdują w serwisach społecznościowych wygodne narzędzia do realizowania swoich celów. Publicyści branżowego portalu PR Newswire radzą, iż precyzyjnie określona grupa docelowa to tylko jedna z możliwości jakie daje płatna reklama na Facebooku. Narzędzie to stale bada i monitoruje upodobania odbiorców, dzięki czemu zakupiona promocja określonego postu jest znacznie wydajniejsza niż w innych tego typu płatnych programach. Ważne jest również określenie głównego celu posiadania konta na Facebooku już na początku działalności danej instytucji: czy jest ono wykorzystywane do rozwijania relacji z mediami i blogerami, czy wpływa na zaangażowanie entuzjastów w swoim rynku, a także budowaniem wśród nich świadomości jej marki ${ }^{29}$. Oprócz budowania relacji i nawiązania kolejnej formy komunikacji z interesującymi publicystami i blogerami można dowiedzieć się więcej o tym, co ich interesuje i co ostatnio napisali, czyli być stale na bieżąco.

Jednak o tym, co serwis wyświetla danemu użytkownikowi w strumieniu wiadomości, decyduje przede wszystkim Edge Rank, czyli opracowany i stale aktualizowany algorytm twórców Facebooka. Dlaczego warto o tym pamiętać tworząc relacje z odbiorcami i kształtując swój elektroniczny wizerunek? Mianowicie nawet jeśli użytkownicy lubią te same fanpage'e oraz mają tych samych znajomych, każdemu z nich serwis może pokazywać odmienne treści. 100 tys. zmiennych wpływa na liczbę wyświetleń naszych postów na Faceboo$\mathrm{ku}$, zamieszczonych na profilu prywatnym lub na facebookowej stronie ${ }^{30}$.

Kształtując PR na Facebooku niemożliwym jest w uwzględnienie nawet części zmiennych Edge Rank. Istotne, aby zwrócić uwagę na przyporządkowanie właściwej kategorii strony utworzonej na Facebooku (biblioteka, edukacja, szkoła wyższa). Kliknięcie w link do serwisu zewnętrznego przeniesie nas poza domenę Facebooka. Po przekierowaniu warto pamiętać, że im dłużej tam pozostaniemy, tym lepiej dla zasięgu naszego wpisu na popularnym portalu. Wszystko po to, aby promować wartościowe treści, a nie sensacyjne i bezużyteczne posty ${ }^{31}$. W tym miejscu pojawia się wyzwanie dla bibliotek, zwłaszcza naukowych, akademickich: w jaki sposób atrakcyjnie zaprezentować siebie, swoją markę, zasoby, aby nie tracić na wiarygodności i wyróżnić się z wielu innych podobnych profili? Czy biblioteki uniwersyteckie to potrafią?

\footnotetext{
${ }^{29}$ S. Skerik, Using Facebook for Public Relations, [w:] PR Newswire, http://www.prnews wire.com/blog/facebook-for-public-relations-1904.html, [dostęp: 21.05.2017].

${ }^{30}$ A. Roguski, Edge Rank dla zaawansowanych, [w:] Why so social?, http://www.whyso social.pl/2014/11/edge-rank-dla-zaawansowanych.html, [dostęp: 23.05.2017].

${ }^{31}$ S. Grzenkowicz, Pierwsze kroki na Facebooku, [w:] Sunrise System, https://www. sunrisesystem.pl/blog/2002-pierwsze-kroki-na-facebooku.html, [dostęp: 23.05.2017].
} 
Autorka artykułu przeprowadziła badania dotyczące sposobu i form wykorzystania narzędzia, jakim jest Facebook, przez wybrane biblioteki uniwersyteckie. Pracę badawczą podzielono na dwie części: analizę zawartości profili bibliotek uniwersyteckich oraz wywiad przeprowadzony z ich administratorami.

\section{Analiza zawartości profili bibliotek uniwersyteckich na Facebooku}

Zgłębiając zjawisko PR $2.0 \mathrm{w}$ bibliotekach poddano analizie zawartość treściową 17 profili założonych przez biblioteki państwowych uniwersytetów o profilu ogólnym (18 biblioteka z listy wyżej określonych, czyli Uniwersytetu Opolskiego, nie posiada konta na portalu społecznościowym Facebook). Podstawowe informacje uzyskano również po przeanalizowaniu infrastruktury Facebooka wykorzystywanej przez administratorów bibliotecznych profili. Obserwowano aktywność profili w ciągu jednego miesiąca (1-31 maj 2017 r.).

Celem badań była odpowiedź na pytanie, za pomocą jakich narzędzi współczesne biblioteki uniwersyteckie kształtują relacje ze swoimi odbiorcami zgromadzonymi wokół popularnego w Polsce i na świecie portalu społecznościowego Facebook? W jaki sposób wykorzystują go do autoprezentacji oraz sprawnej komunikacji? Jak PR 2.0 oceniają na Facebooku użytkownicy danych bibliotek? W tym celu posłużono się metodą ilościową, której towarzyszyła analiza użyteczności. Badanie koncentrowało się na wykorzystywaniu tablicy pod względem:

- $\quad$ autoprezentacji (użyte awatary, zdjęcia w tle, znaczniki do wyszukiwania);

- $\quad$ analizy różnego typu treści (wiadomość, link, zdjęcie):

- różnych źródeł treści (własnych i udostępnianych);

- $\quad$ komunikatywności (przyciski kontaktowe, czas odpowiedzi);

- $\quad$ skuteczności działań PR na Facebooku, czyli ocena jego społecznego odbioru (recenzje, liczba fanów, obserwujących, zameldowań).

\section{Autoprezentacja}

Z punktu widzenia użytkownika niezwykle istotna jest łatwość identyfikowania danej instytucji, w tym przypadku bibliotek uniwersyteckich. Utrudnieniem mogą być różne formy nazw, tworzone w zależności od medium. Aby uniknąć nieporozumień wyszukiwawczych najlepiej właściwy profil biblioteki odszukać poprzez stronę domową biblioteki, na której powinien znajdować się widżet kierujący do jej profilu na Facebooku. Nazwy bibliotek w danym serwisie społecznościowym to kombinacje skrótów i części nazw oficjalnych. Raz 
Nazwy identyfikujące biblioteki uniwersyteckie na Facebooku

\begin{tabular}{|c|c|c|}
\hline Nazwa oficjalna & Nazwa na Facebooku & Znacznik wyszukiwania \\
\hline $\begin{array}{l}\text { 1. Biblioteka Uniwersytec- } \\
\text { ka w Warszawie }\end{array}$ & $\begin{array}{l}\text { Biblioteka Uniwersytecka } \\
\text { w Warszawie }\end{array}$ & @BUWnaDOBREJ \\
\hline $\begin{array}{l}\text { 2. Biblioteka Uniwersytec- } \\
\text { ka im. Jerzego Giedroycia } \\
\text { w Białymstoku }\end{array}$ & $\begin{array}{l}\text { Biblioteka Uniwersytecka } \\
\text { im. Jerzego Giedroycia } \\
\text { w Białymstoku }\end{array}$ & brak \\
\hline $\begin{array}{l}\text { 3. Biblioteka Uniwersytetu } \\
\text { Gdańskiego }\end{array}$ & $\begin{array}{l}\text { Biblioteka Uniwersytetu } \\
\text { Gdańskiego }\end{array}$ & @BUGloteka \\
\hline $\begin{array}{l}\text { 4. Biblioteka Uniwersytec- } \\
\text { ka w Poznaniu }\end{array}$ & $\begin{array}{l}\text { Biblioteka Uniwersytecka } \\
\text { w Poznaniu }\end{array}$ & $\begin{array}{l}@ \text { BibliotekaUniwersytecka } \\
\text { wPoznaniu }\end{array}$ \\
\hline 5. Biblioteka Jagiellońska & Biblioteka Jagiellońska & @ BibliotekaJagiellońska \\
\hline $\begin{array}{l}\text { 6. Biblioteka Uniwersytetu } \\
\text { Łódzkiego }\end{array}$ & $\begin{array}{l}\text { Biblioteka Uniwersytetu } \\
\text { Łódzkiego }\end{array}$ & @BibliotekaUL \\
\hline $\begin{array}{l}\text { 7. Biblioteka UMCS } \\
\text { w Lublinie }\end{array}$ & Biblioteka UMCS & (a)BibliotekaUMCS \\
\hline $\begin{array}{l}\text { 8. Biblioteka Uniwersytec- } \\
\text { ka UMK w Toruniu }\end{array}$ & $\begin{array}{l}\text { Biblioteka Uniwersytecka } \\
\text { w Toruniu }\end{array}$ & (a)bu_torun \\
\hline $\begin{array}{l}\text { 9. Biblioteka Główna Uni- } \\
\text { wersytetu Szczecińskiego }\end{array}$ & $\begin{array}{l}\text { Biblioteka Główna Uni- } \\
\text { wersytetu Szczecińskiego }\end{array}$ & $\begin{array}{l}\text { @BBiblioteka.Glowna. } \\
\text { Uniwersytetu.Szczecinskiego }\end{array}$ \\
\hline $\begin{array}{l}\text { 10. Biblioteka Uniwersytetu } \\
\text { Śląskiego }\end{array}$ & $\begin{array}{l}\text { Centrum Informacji } \\
\text { Naukowej i Biblioteka } \\
\text { Akademicka - Ciniba }\end{array}$ & @CINIBAofficial \\
\hline $\begin{array}{l}\text { 11. Biblioteka Uniwersytetu } \\
\text { Rzeszowskiego }\end{array}$ & Biblioteka UR & (a) BibliotekaUR \\
\hline $\begin{array}{l}\text { Biblioteka Uniwersytecka } \\
\text { UWM w Olsztynie }\end{array}$ & $\begin{array}{l}\text { Biblioteka Uniwersytecka } \\
\text { UWM w Olsztynie }\end{array}$ & (a)buuwm \\
\hline $\begin{array}{l}\text { 12. Biblioteka Uniwersytec- } \\
\text { ka we Wrocławiu }\end{array}$ & $\begin{array}{l}\text { Biblioteka Cyfrowa Uni- } \\
\text { wersytetu Wrocławskiego }\end{array}$ & (a) BCUWr \\
\hline $\begin{array}{l}\text { 13. Biblioteka Uniwersytetu } \\
\text { Kardynała Stefana Wyszyń- } \\
\text { skiego w Warszawie }\end{array}$ & Biblioteka UKSW & @bibliotekauksw \\
\hline $\begin{array}{l}\text { 14. Biblioteka Uniwersytetu } \\
\text { Zielonogórskiego }\end{array}$ & Biblioteka UZ & brak \\
\hline $\begin{array}{l}\text { 15. Biblioteka Uniwersytetu } \\
\text { Kazimierza Wielkiego } \\
\text { w Bydgoszczy }\end{array}$ & $\begin{array}{l}\text { Biblioteka Uniwersytetu } \\
\text { Kazimierza Wielkiego }\end{array}$ & @bibliotekaUKW \\
\hline $\begin{array}{l}\text { 16. Biblioteka Uniwersytec- } \\
\text { ka Uniwersytetu Jana Ko- } \\
\text { chanowskiego w Kielcach }\end{array}$ & $\begin{array}{l}\text { Biblioteka Uniwersytecka } \\
\text { w Kielcach }\end{array}$ & $\begin{array}{l}\text { @biblioteka.uniwersytecka. } \\
\text { kielce }\end{array}$ \\
\hline
\end{tabular}

Źródło: badanie własne. 
wprowadzony do identyfikacji biblioteki znacznik wyszukiwania powinien być używany w tej samej formie na wszystkich profilach w mediach społecznościowych.

Jak wykazano w tab. 1 oficjalne nazwy bibliotek uczelnianych różnią się od tych, którymi posługują się one na Facebooku. Najczęściej używane są skróty literowe, którym towarzyszy nazwa biblioteka. W przypadku Biblioteki Uniwersyteckiej we Wrocławiu utworzony został profil, którego celem jest promocja zasobów Biblioteki Cyfrowej. Niestety brak konsekwencji można również zaobserwować w nazewnictwie znaczników wyszukiwania.

Przy autoprezentacji biblioteki uniwersyteckiej na Facebooku warto pamiętać o zamieszczeniu podstawowych informacji: krótkiego opisu działalności lub misji biblioteki, aktualnego logo i zdjęcia w tle. Elementy te służą szybkiej identyfikacji i wpływają na odbiór danego profilu przez użytkowników. Niestety nie wszystkie spośród badanych bibliotek uzupełniły zakładkę Informacje wpisem na temat historii, zadań czy misji danej placówki. Na trzech profilach (18\% ogółu) pozostawiono to pole bez uzupełnienia. Zdecydowana większość bibliotek umieściła na swoim koncie dobrze przygotowaną autoprezentację. Podobnie dzieje się z pozostałymi częściami identyfikacji wizualnej profilu. Badane placówki w miejscu zdjęcia profilowego (awatara) preferowały umieszczenie logo biblioteki ( $88 \%$ ogółu), na których aż w 9 spośród 17 przypadków dominował tradycyjny kolor akademicki - niebieski. Pozostałe $12 \%$ wybrały zwyczajowe fotografie. Zdjęcia umieszczane w tle profilu bibliotecznego to najczęściej wizerunki charakterystycznego elementu budynku (wnętrza lub fasady) - tak było na $70 \%$ profili bibliotek uniwersyteckich. Pozostałe $30 \%$ administratorów skorzystało z grafiki przygotowanej dla danej instytucji (na przykład reklamującej nocne dyżury).

Wśród wykorzystywanych narzędzi dostępnych w serwisie Facebook, a przydatnych $\mathrm{w}$ prowadzeniu public relations przez biblioteki można wymienić:

- podstawowe (Oś czasu, Informacje, Zdjęcia, Opinie, Osoby, które to lubią);

- dodatkowe (Filmy, Wydarzenia, Notatki), tworzone przez administratorów profilu;

- $\quad$ tak zwane indywidualizujące (Zapytaj Bibliotekarza, Plan BUW, Watch Docs, BUW na YouTube, BUW na Dobrej, Katalog Podstawowy, Katalog online, Jagiellońska Biblioteka Cyfrowa, Welcome, Lubię BUR, Zagadaj do nas).

Służą one wielokanałowemu dotarciu z ofertą do użytkowników biblioteki. Średnio na profilu uniwersyteckich książnic widocznych jest 8 zakładek. Interesującym jest fakt, że Biblioteka Uniwersytecka w Warszawie ma ich aż 
14 i wykorzystuje je w znacznej części do przekierowania odbiorców na profil Biblioteki tworzony w innym serwisie społecznościowym (na przykład Instagram, Google +).

\section{Komunikatywność}

Podstawowym zaleceniem, które wyróżnia komunikowanie się $\mathrm{z}$ otoczeniem za pomocą profilu na Facebooku, jest jego znaczna „interaktywność komunikatów oraz ukierunkowanie komunikacji na przekaz dwustronny"32. Chodzi tu nie tylko komunikację biblioteka-użytkownik, ale również użytkownik-użytkownik. Przykładem tego typu komunikacji są profile typu Spotted (miejsce), tworzone również przez gości bibliotek (na przykład Spotted: Biblioteka UWM, Spotted: Biblioteka UMCS, Spotted: Biblioteka BJ - Biblioteka Jagiellońska). Profile bibliotek nie powinny stanowić duplikatów innych form ich aktywności w Internecie, czyli zamieszczać treści kopiowane ze stron domowych bibliotek czy prowadzonych przez nie blogów. Facebook jako serwis społecznościowy wymaga komunikacji, która będzie angażować fana profilu, czyli internautę zainteresowanego z określonych powodów obserwacją działań biblioteki. Jeśli odbiorca wykryje powtarzalność tych samych wpisów na różnych jej profilach, prawdopodobnie przestanie $\mathrm{z}$ nich korzystać.

W celu zwiększenia kontaktu $\mathrm{z}$ fanem profilu bibliotecznego i zapewne samej biblioteki wykorzystuje się przyciski. Są to uwidocznione duże elementy profilu, dzięki którym poszukujący informacji może szybciej dotrzeć do obsługującego je bibliotekarza. Przyciski przybierają różne: Zadzwoń teraz (stosuje 8 bibliotek uniwersyteckich), Wiadomości (9 bibliotek eksponuje dojście do wbudowanego w środowisko Facebooka komunikatora Messenger), Wyślij wiadomość (stosują 4 biblioteki), Skontaktuj się z nami (stosują 3 biblioteki). Tak jak w przypadku zakładek przyciski można indywidualizować, co wykorzystuje Biblioteka UMK w Toruniu, która posiada przycisk Dowiedz się więcej, czy Biblioteka UMCS w Lublinie, która proponuje dodatkowo wysłanie maila.

$\mathrm{Na}$ ich tablicach profilowych na Facebooku umieszczane są często informacje o czasie, w jakim dana organizacja udziela odpowiedzi. Z pewnością mobilizuje to administratorów do jak najszybszego reagowania na pozostawiane w skrzynce wiadomości, zaś użytkownicy posiadają informację o stopniu

${ }^{32}$ M. Kaczmarek-Śliwińska, Social media $w$ dzialaniach internet PR przedsiębiorstw polskiego rynku, [w:] Public relations we współczesnym świecie..., s. 148. 
komunikatywności danych redaktorów treści. Analiza profili bibliotek uniwersyteckich wykazała, że odznaczają się one dobrą responsywnością i szybko odpowiadają na zapytania: 4 kontaktują się wciągu kilku minut, $2 \mathrm{w}$ ciągu godziny, 2 w ciągu kilku godzin, 3 w ciągu dnia. Tylko jedna biblioteka uniwersytecka potrzebuje na odpowiedź więcej niż jeden tydzień.

W komunikatywności ważny jest dobór komunikatu oraz jego częstotliwość. To jak często o sobie przypominamy naszym fanom w decyduje, o tym czy prowadzony przez bibliotekę profil jest aktywnym uczestnikiem życia wirtualnej społeczności. Bez odpowiednio częstej aktualizacji profilu szybko może być uznany za nieatrakcyjny lub pozbawiony znaczenia. Choć w badanym okresie (maj 2017 r.) biblioteki angażują się w obchody wielu wydarzeń związanych z czytelnictwem i bibliotekami, częstotliwość umieszczanych postów na Facebooku jest skrajnie różna (rys. 1).

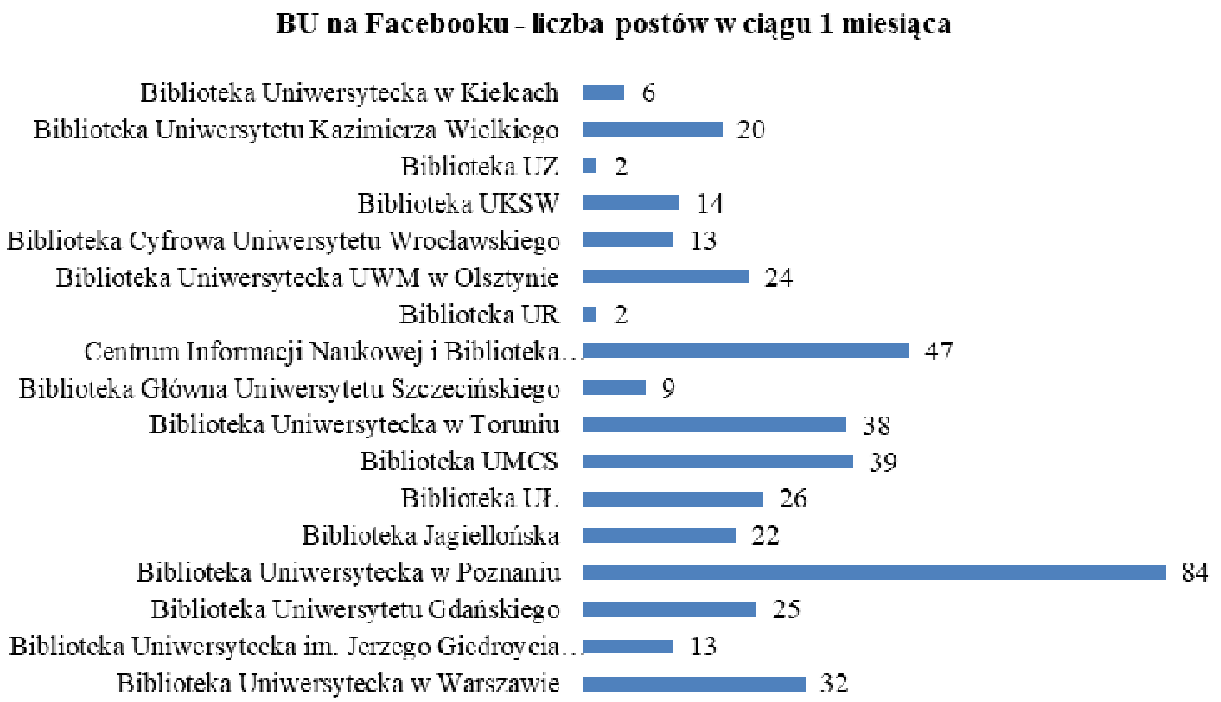

Rys. 1. Liczba wpisów umieszczanych przez biblioteki uniwersyteckie na Facebooku w ciągu 1 miesiąca aktywności

Źródło: badanie własne.

W badanym okresie najwięcej postów zamieszczali administratorzy Biblioteki Uniwersyteckiej w Poznaniu (BUP) (84 wpisy). Jednak warto uzupełnić, iż na tę sytuację ma pływ posiadanie przez daną bibliotekę kilku tematycznych profili. Profilem głównym, kompensującym treść z pozostałych był profil Biblioteki Uniwersyteckiej w Poznaniu, który udostępnia ich treści. 
Co najmniej raz dziennie posty umieszczano ponadto na profilach: Centrum Informacji Naukowej i Biblioteki Akademickiej, (CINiB-y, 47 wpisów), Biblioteki UMCS (39 wpisów), Biblioteki Uniwersyteckiej w Toruniu (38 wpisów) oraz Biblioteki Uniwersyteckiej w Warszawie (32 wpisów). Dwie aktualizacje w ciągu miesiąca (Biblioteki Uniwersytetu Zielonogórskiego i Rzeszowskiego) to zdecydowanie za mało, aby nawiązać jakiekolwiek relacje z społecznością, mogącą się zainteresować profilem biblioteki.

\section{BU na Facebooku - preferowane typy treści}

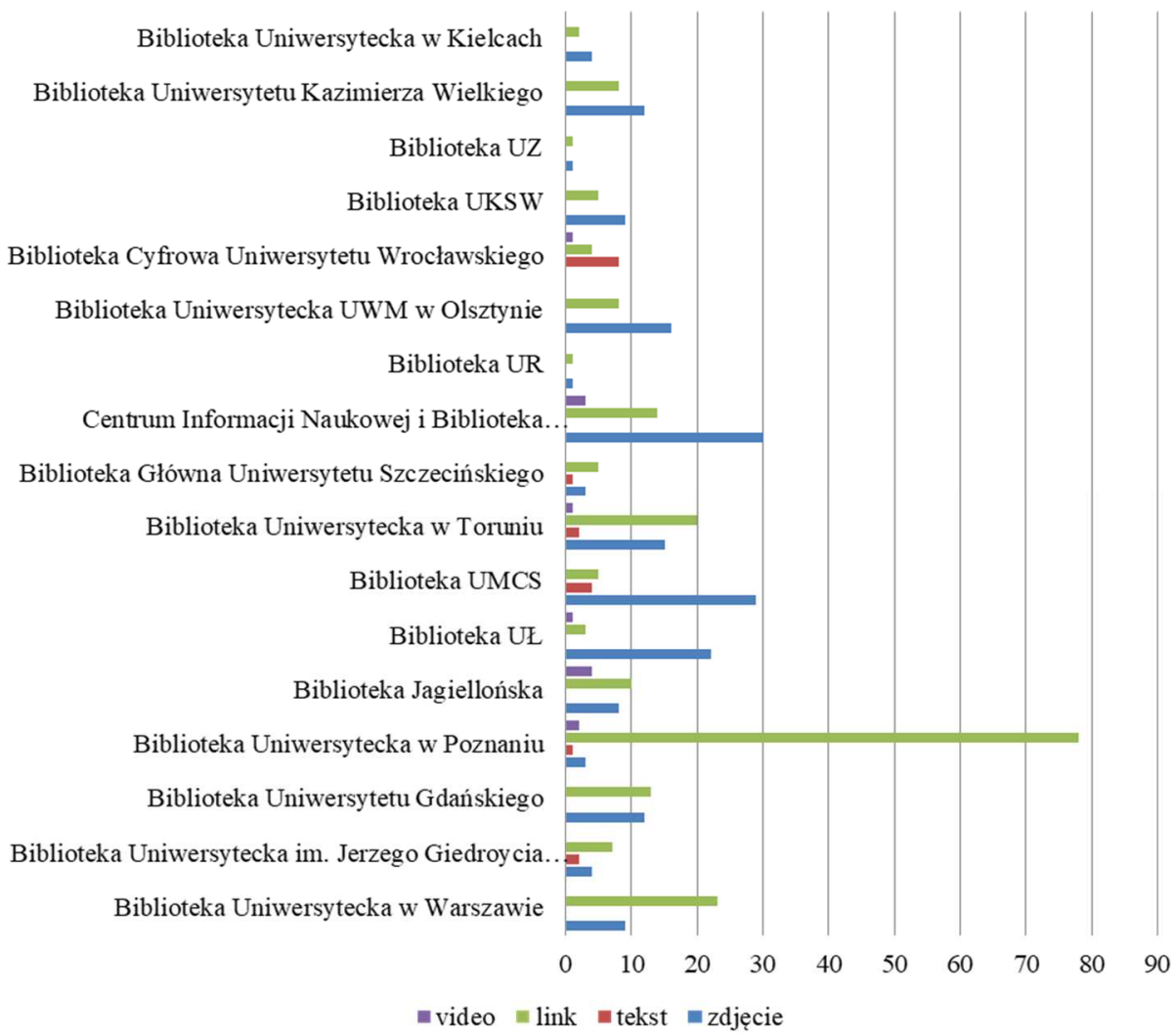

Rys. 2. Formy postów zamieszczanych przez biblioteki uniwersyteckie na Facebooku

Źródło: badanie własne. 
W środowisku mediów społecznościowych preferowane są wszelkie formy wizualne ${ }^{33}$. Użytkownik zasobu Internetowego przegląda je szybko, raczej nie czyta, a skanuje wzrokiem. W związku z powyższym biblioteczny PR 2.0, aby był skuteczny, powinien być oparty na bogatym zasobie zdjęciowograficznym, nagraniach wideo i krótkich treściach. Twórcy bibliotecznych profili sięgają po wszystkie wspomniane formy udostępniania treści (rys. 2).

Posiadanie kilku profili na Facebooku przez Bibliotekę Uniwersytecką w Poznaniu wpłynęło również na fakt, że na jej głównej tablicy najczęściej pojawiają się udostępniane linki. Działanie to zwiększa zasięg profilu, który udostępnia treści niż buduje sukces profilu głównego. Wśród pozostałych bibliotek uniwersyteckich $\mathrm{w}$ badanym okresie najpopularniejszą formą umieszczanych postów były zdjęcia ( $43 \%$ wszystkich postów). Fotografie umieszczane były najczęściej na profilu CINiB-y (30 postów), Biblioteki UMCS (29 postów), Biblioteki UŁ (22 postów) oraz Biblioteki Uniwersyteckiej UWM w Olsztynie (16 postów) i Biblioteki Uniwersyteckiej w Toruniu (15 postów). Zaś wideo (4\% ogółu postów) i tekst (1\% ogółu postów), których autorami byli administratorzy profilu bibliotecznego, stanowiły zdecydowaną mniejszość wpisów na Facebooku w badanym okresie. O małej popularności filmów jako formy postu może przesądzać czasochłonność i koszty jego produkcji. Z drugiej strony posty, w których opublikowany jest wyłącznie tekst może być wręcz nie zauważony przez użytkownika serwisu Facebook.

Ważnym elementem tworzenia wizerunku jest jakość i stylistyka publikowanych treści. Jeśli administratorzy upubliczniając wytworzone przez siebie treści potrafią nadać wysoki poziom swojej pracy i prezentują fachowe podejście do prowadzenia profilu, ma to pozytywny wpływ na odbiór wizerunku instytucji. Profesjonalnie wykonane i przygotowane do publikacji zdjęcia, estetyczne i dobrej jakości grafiki, czy opracowane teksty, wysoko pozycjonujące profil biblioteki na Facebooku, w istotny sposób wpływają na kreowany w sieci wizerunek. Poddane analizie biblioteki uniwersyteckie w zdecydowanej większości upubliczniają treści własne (rys. 3).

Dzięki udostępnianiu treści pokrewnych profili, procentowo najwięcej własnych postów udostępniła Biblioteka Uniwersytetu w Poznaniu. Do grupy liderów, biorąc pod uwagę samodzielność wytwarzania upublicznianych treści na Facebooku, należały: CINiBA (41 postów), Biblioteka UMCS (37 postów), Biblioteka w Toruniu (32 posty), Biblioteka UŁ (23 posty) oraz Biblioteka Uniwersytecka UWM w Olsztynie (21 postów).

${ }^{33}$ A. Walecka-Rynduch, Wideoideologia i youtubizacja jako narzędzia politycznego public relations, „Politeja” 2013, nr 25, s. 481-499. 


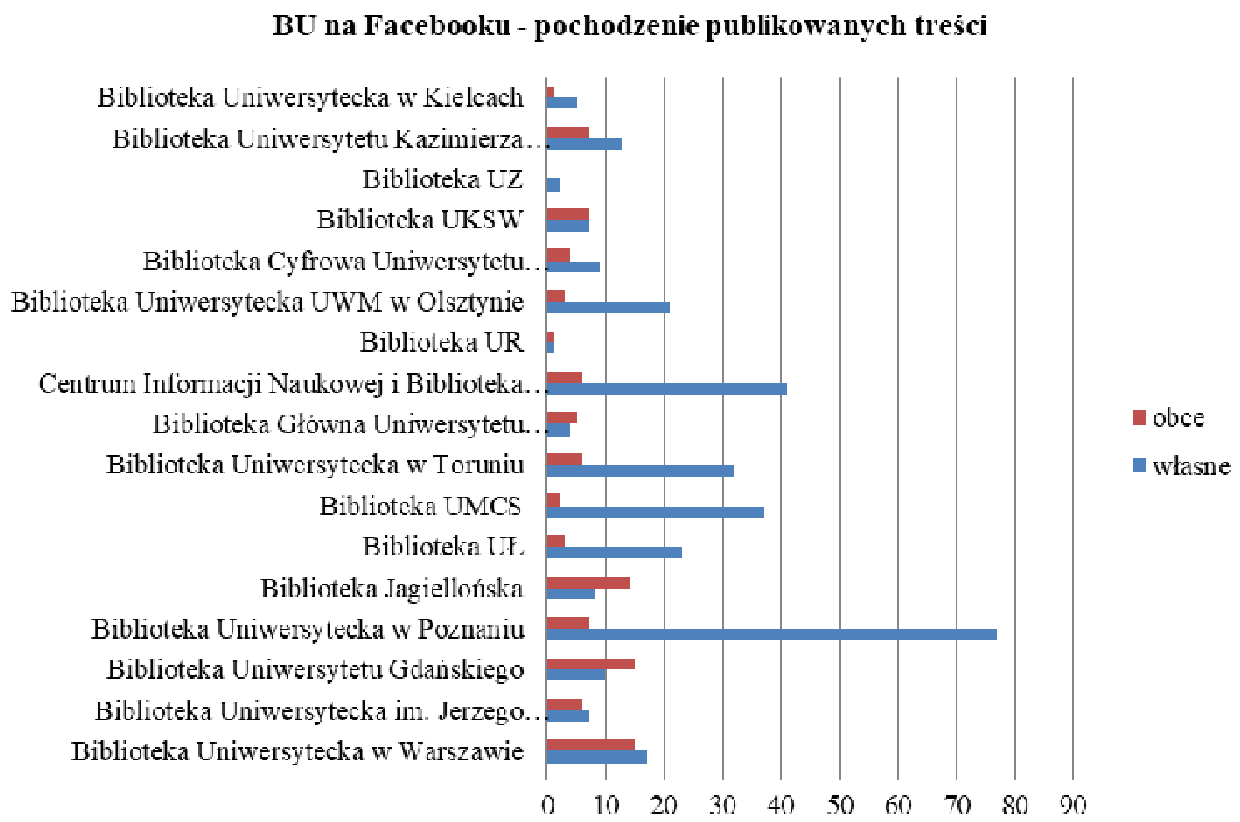

Rys. 3. Autorstwo postów udostępnianych przez biblioteki uniwersyteckie na Facebooku

Źródło: badanie własne.

\section{Skuteczność PR}

O popularności profilu i dobrych relacjach z użytkownikami świadczy liczba jego polubień. Skutecznym PR 2.0 może pochwalić się Biblioteka Uniwersytecka w Warszawie, która posiada trzykrotnie większą liczbę fanów, niż pozostałe profile bibliotek. Można przypuszczać, iż atrakcyjność budynku i umiejscowienie go w centrum miasta miały wpływ na tę sytuację. $Z$ tych powodów liczba użytkowników biblioteki oraz odwiedzających profil zwiększa się o osoby spoza uczelni, które uległy po części modzie na bywanie w BUW, czyli buwingowi.

Istotnym składnikiem oceny zainteresowania działaniami bibliotek uniwersyteckich na Facebooku są obserwacje ich profili (polubienie profilu nie oznacza jego obserwacji). Jednak w przypadku badanych placówek blisko $100 \%$ lubiących stale obserwuje aktualizacje na danym profilu $(96,3-99,1 \%)$. Kolejnym wskaźnikiem ukazującym atrakcyjność bibliotek uniwersyteckich na najpopularniejszym serwisie społecznościowym jest geolokalizacja, czyli zameldowanie się $\mathrm{w}$ danym miejscu, zaznaczenie w sieci swojego pobytu w bibliotece. 


\section{BU na Facebooku - liczba fanów}

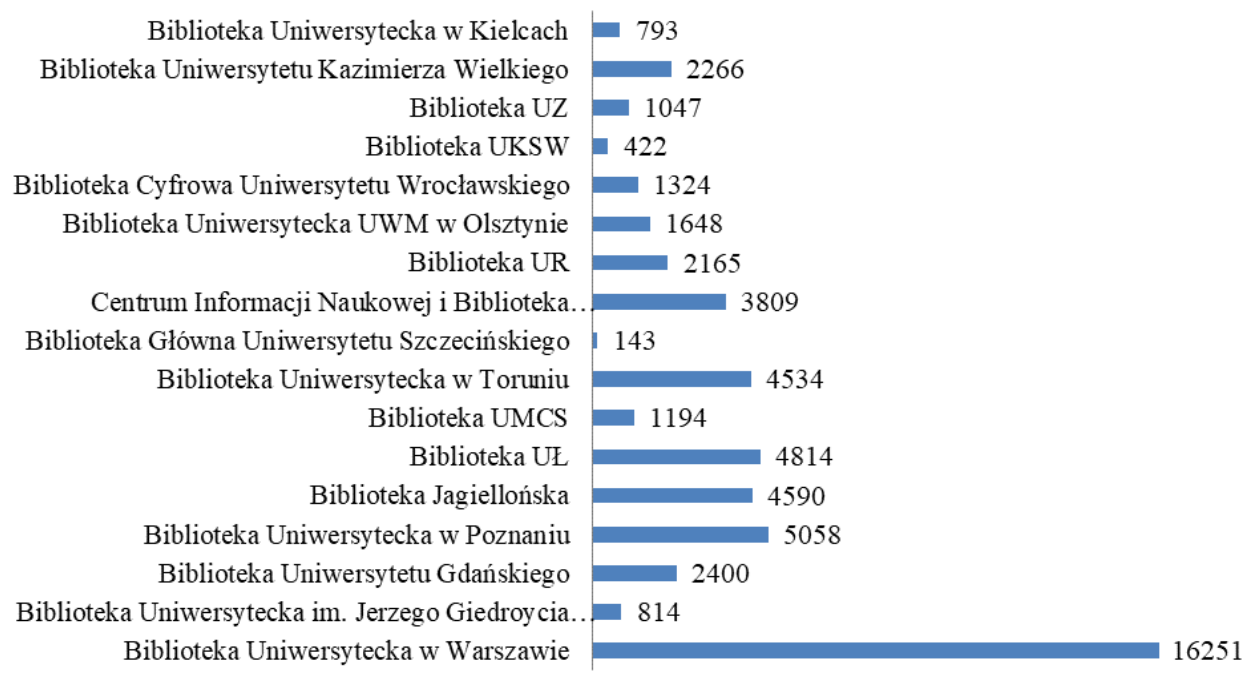

Rys. 4. Liczba fanów bibliotek uniwersyteckich na Facebooku

Źródło: badanie własne.

Wysoka liczba fanów czy obserwujących nie gwarantuje zaznaczenia swojej obecności w danym miejscu. Ważny wydaje się fakt, czy użytkownicy bibliotek uznają pobyt w danym miejscu za godny odnotowania. Spośród badanych placówek odwiedzający najczęściej odnotowują na Facebooku swój pobyt w Bibliotece Uniwersyteckiej UWM w Olsztynie (1262 zameldowań w stosunku do 1618 ogólnej liczby polubień profilu biblioteki na Facebooku). Można się domyślać, iż wpływ na tę sytuację ma atrakcyjność przestrzeni bibliotecznych, centralne umiejscowienie biblioteki na trenie kampusu uniwersyteckiego i oferta wydarzeń kulturalno-edukacyjnych, która kierowana jest często do społeczności o zasięgu ponad uczelnianym. Duże znaczenie wizerunkowe w środowisku sieciowym miała również kampania Biblioteki Uniwersyteckiej UWM zatytułowana Oznacz się hashtagiem w bibliotece, w ramach której zorganizowano konkurs fotograficzny. W tracie obchodów Ogólnopolskiego Tygodnia Bibliotek 2017 do każdego zamówienia książek z magazynu dołączano zakładkę z hasłem \#buuwm, zaś w przestrzeni fizycznej Biblioteki umieszczono kartonowy napis o wymiarach $1 \mathrm{~m} / 5,5 \mathrm{~m}$. Użytkownicy Biblioteki Uniwersyteckiej Uniwersytetu Kazimierza Wielkiego w Bydgoszczy równie często lubili jej profil i oznaczali swój pobyt (1417 zameldowań w porównaniu do 2264 polubień profilu), podobnie było w Centrum Informacji Naukowej i Bibliotece Akademickiej w Katowicach (1758 zameldowań na 3809 polubień 
facebook'owego fanpage Biblioteki). Ostatnia $\mathrm{z}$ wymienionych instytucji w pomysłowy sposób promuje tradycyjne zasoby w środowisku Web 2.0. Do krótkiego opisu elementu zasobu (na przykład nowości książkowych) dodawany jest hashtag \#MaszTowCinibie, dzięki któremu świadomość zasobów bibliotecznych wzrasta i są one łatwiej wyszukiwane przez użytkowników.

Społeczna ocena profili bibliotek uniwersyteckich wyraża się również poprzez zamieszczanie ich recenzji (zaznaczanie od 1 do 5 gwiazdek, z możliwością komentowania swojej opinii). Niektóre biblioteki pozbawiają swych użytkowników takiej formy ewaluacji, ale zdecydowana większość z niej korzysta i wypada w tych ocenach bardzo dobrze (rys. 5). Średnia ocena profilu

\section{BU na Facebooku - recenzja}

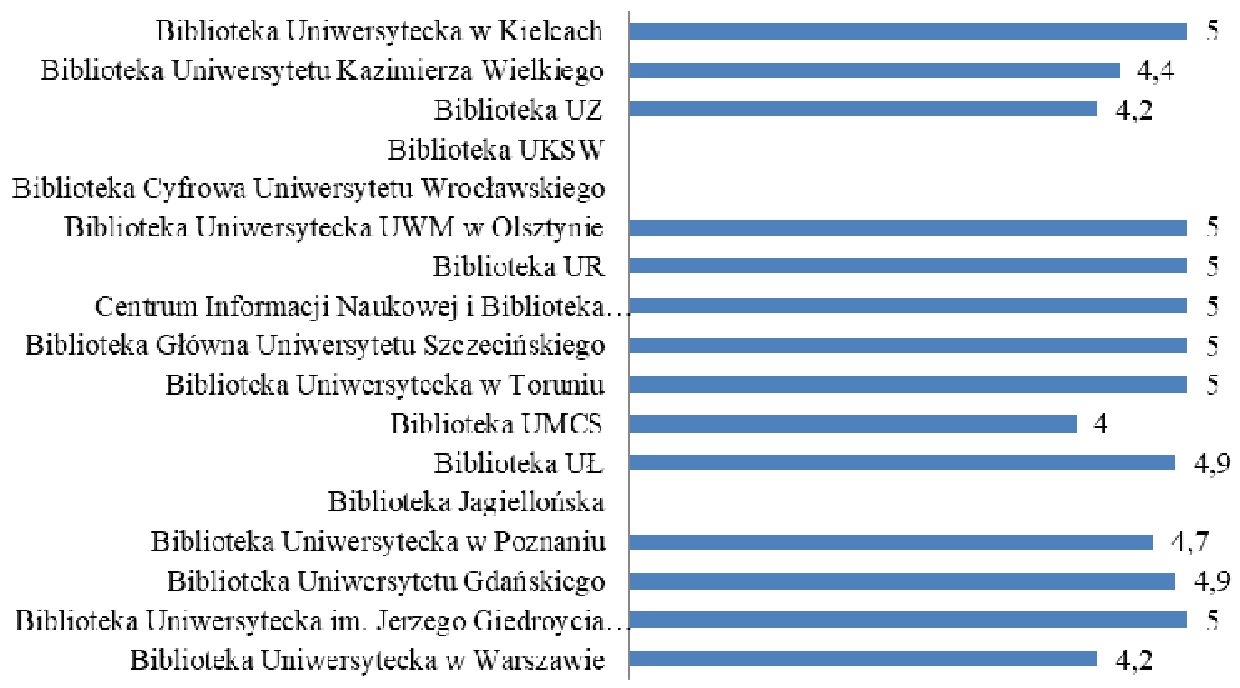

Rys. 5. Ocena profili bibliotek uniwersyteckich na Facebooku (w skali 1-5) Źródło: badanie własne.

Możliwość recenzowania bywa niestety formą odreagowania jednostkowych incydentów, czy powodów niezadowolenia z usług biblioteki. Otwartość w Internecie umożliwia łatwą krytykę. Wystawienie pojedynczej najniższej oceny (1) może spowodować drastyczny spadek ogólnej oceny profilu biblioteki, co z kolei ma negatywny wpływ na wizerunek instytucji i obniża jej wiarygodność. 


\section{Wywiad $\mathrm{z}$ administratorami}

Analizę zawartości profili bibliotek uniwersyteckich na Facebooku uzupełniono opisem wyników wywiadu wystosowanego do administratorów tychże profili. Wywiad kwestionariuszowy składał się z sześciu pytań: czterech otwartych i dwóch zamkniętych (jednokrotnego wyboru), w tym jedno z zastosowaniem odpowiedzi ułożonych w skali Lickerta. Uzyskano 12 odpowiedzi (spośród 16 wysłanych wiadomości za pomocą komunikatora Messenger oraz 1 za pomocą poczty mailowej).

W pytaniu pierwszym poproszono o wskazanie liczby osób administrujących biblioteczne profile. Wyniki analizy 12 nadesłanych ankiet ujawniły, iż najczęściej profil biblioteki uniwersyteckiej prowadzą cztery osoby. Na uwagę zasługuje Biblioteka Uniwersytetu Poznańskiego, której profil administruje aż 8 osób. Polityka aktywności poznańskiej Biblioteki uwzględnia prowadzenie, oprócz głównego profilu, kilku uzupełniających - tematycznych, między innymi: Galeria Biblioteki Uniwersyteckiej (24 fanów), NOVA. Czytelnia Komiksów i Gazet (2414 fanów), PRESSto, czyli platforma czasopism elektronicznych Uniwersytetu Adama Mickiewicza w Poznaniu (201 fanów). Pracownicy BUP prowadzą również profile cyklicznych wydarzeń, jak na przykład comiesięczne spotkania miłośników gier planszowych zatytułowane „W Bibliotece wszystko gra!” Tego typu aktywność jest obecnie powszechna w wielu bibliotekach, w tym również uniwersyteckich, chcących wyróżnić niektóre wydarzenia i oddzielnie promować je na Facebooku.

Pytanie drugie dotyczyło korzystania z płatnej promocji przez administratorów bibliotek uniwersyteckich. Tylko jedna biblioteka korzystała z tej opcji. Analiza odpowiedzi wskazała na cele wizerunkowe związane z posiadaniem konta w serwisie społecznościowym Facebook. Administratorzy profili bibliotek uniwersyteckich wytypowali cechy ważne dla wizerunku instytucji jaką reprezentują. Biblioteka uniwersytecka na Facebooku powinna być: przyjazna (7 odpowiedzi), otwarta (6), nowoczesna (5), profesjonalna (4), promująca kulturę (3), promująca naukę (3), interesująca i atrakcyjna (2), użyteczna (1).

Kolejne pytanie odnosiło się do kryzysu wizerunkowego. U 50\% badanych nie odnotowano niekorzystnych wizerunkowo incydentów. Jednak na pozostałych sześciu profilach pojawiły sytuacje kryzysowe, wśród których wymieniono: negatywną recenzję biblioteki uzupełnioną niemilym komentarzem (4 odpowiedzi), krytykę kosztów ksero umieszczonego w bibliotece (1) oraz upublicznione na Facebooku informacje na temat spotkania przed budynkiem biblioteki młodzieży należącej do skrajnie prawicowego ugrupowania (1). Uzupełnieniem pytania była prośba o wskazanie sposobu poradzenia sobie z chwilowym impasem. Biblioteki, które zmierzyły się z problemem kryzysu 
wizerunkowego, aż w pięciu przypadkach podjęły próbę wyjaśnienia (skomentowały dany fakt), zaś jedna zarządziła incydentalną zmianę w funkcjonowaniu biblioteki.

Pozytywny wpływ na PR 2.0 mają przypadki sukcesów wizerunkowych. To one powodują, że biblioteka dzięki obecności w mediach społecznościowych wykracza daleko poza obręb swojej standardowej grupy docelowej. Odpowiedzi na pytanie piąte wskazywały przykłady rozpoznawalnych, zapamiętywanych i rozpowszechnianych masowo postów, które promowały atrakcyjny wizerunek danej bibliotek. Sukcesy wizerunkowe w wersji 2.0 dotyczą przede wszystkim środowiska wirtualnego. Przykładem takiego postu jest rysunek $\mathrm{w}$ formie memu internetowego, przygotowany przez rysowniczkę Beatę Gamrowską - pracownika Sekcji Promocji Biblioteki Uniwersytetu Łódzkiego (rys. 6) oraz odpowiednio opracowane graficznie zdjęcie Biblioteki Uniwersytetu Gdańskiego (rys. 7).

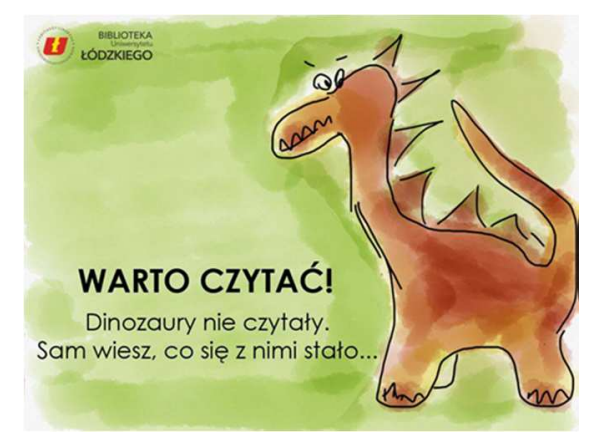

Rys. 6. Przykład sukcesu wizerunkowego biblioteki uniwersyteckiej na Facebooku - rysunek

Źródło: https://www.facebook.com/BibliotekaUL/photos, [dostęp: 01.06.2017].

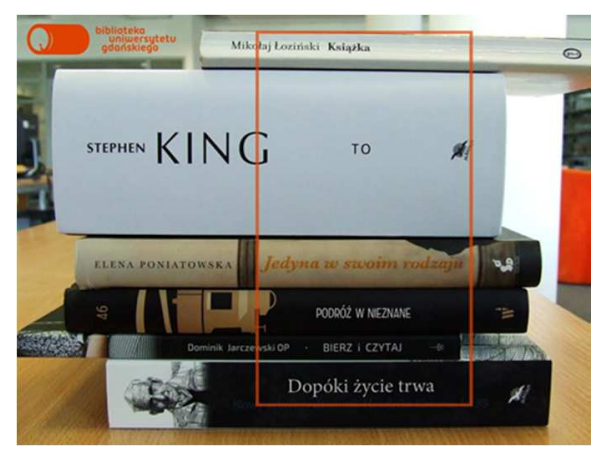

Rys. 7. Przykład sukcesu wizerunkowego biblioteki uniwersyteckiej na Facebooku - grafika

Źródło: https://www.facebook.com/BUGloteka/photos, [dostęp: 01.06.2017]. 
Analiza odpowiedzi na pytanie piąte ukazała również, iż sukces wizerunkowy wsparty przez media społecznościowe może dotyczyć tradycyjnej przestrzeni biblioteki uniwersyteckiej. W przypadku Biblioteki Uniwersyteckiej UWM w Olsztynie użytkownicy docenili oryginalność choinki zbudowanej z kart katalogowych, zaś odwiedzający popularną CINiB-ę zagustowali w dogodnościach funkcjonalnych kącików pufowych, znajdujących się w ich bibliotece. Wśród odpowiedzi pozostałych ośmiu bibliotek wymieniano najczęściej pozytywne komentarze i recenzje profilu czy masowe polubienia pojedynczych zdjęć oraz galerii udostępnianych przez biblioteki na ich profilach.

Odpowiedzi na ostatnie pytanie miały wskazać typy facebookowych profili, z którymi najchętniej wchodzą w relacje administratorzy uczelnianych bibliotek. Wśród najatrakcyjniejszych partnerów do sieciowych interakcji (polubień, komentarzy, udostępniania postów) wymieniono: profile o tematyce bibliotekarskiej (średnia ocena przydatności relacji to 4,9) oraz profile wydziałów uniwersytetu $(4,9)$. Niemniej interesujące okazały się facebookowe strony uniwersytetów $(4,8)$ oraz profile promujące czytelnictwo $(4,8)$. Grupę atrakcyjnych partnerów zamykają media uniwersyteckie (4.4) oraz profile kierunkowe/ instytutowe uniwersytetu $(4,1)$. Administratorzy profili badanych bibliotek w stopniu umiarkowanym inicjują na Facebooku kontakty z takimi podmiotami jak: instytucje naukowo-badawcze $(3,8)$, instytucje kultury $(3,8)$, osoby związane z kulturą $(3,7)$, osoby związane z nauką $(3,7)$, koła naukowe uniwersytetu $(3,7)$, grupy tematyczno-branżowe związane z kierunkami kształcenia uniwersytetu $(3,6)$, grupy tematyczno-studenckie $(3,6)$, towarzystwa i stowarzyszenia $(3,5)$, władze studenckie - RUSS $(3,4)$, media regionalne $(3,2)$, grupy tematyczno-regionalne $(3,1)$. W budowaniu PR 2.0 badanych bibliotek uniwersyteckich najmniej istotne okazały się profile: osób prywatnych $(2,5)$, szkół $(2,5)$, firm $(2,4)$, o charakterze rozrywkowym $(2,1)$ oraz mediów ogólnopolskich $(2,1)$. Odpowiedzi na ostatnie pytanie nasuwają wniosek, że im partner relacji bliższy grupy docelowej (środowisko związane z uniwersytetem, regionem, nauką), tym chętniej administrator profilu biblioteki uniwersyteckiej aktywizuje swoje zainteresowanie za pomocą komentarza czy udostępnienia zamieszczonych treści. Potwierdza tę taktykę publicystka PR Newswire, Sarah Skerik, w słowach: „Każdy strategista mediów społecznych wart swojej pensji powie, że pierwszym krokiem w planowaniu strategii w sieciach społecznościowych jest słuchanie [...]. Znajdź aktywne grupy skupiające się na istotnych tematach i dołącz do nich. Spędzaj większość czasu na słuchaniu i obserwowaniu" 34 .

\footnotetext{
${ }^{34}$ S. Skerik, Using Facebook...
} 


\section{Podsumowanie}

Z przeprowadzonych badań wynika, iż Facebook cieszy się dużą popularnością wśród polskich bibliotek. Aktywnie tworzą one swoje profile, inicjują kontakty, kształtują komunikację i kreują wizerunek. Działania podejmowane są ostrożnie, po bacznej obserwacji, czasem naśladowaniu konkurencji, zdarza się również, że odznaczają się innowacyjnością, by uzyskać oryginalną strategię PR. Poziom komunikowania poprzez profile społecznościowe oraz obszar Web 2.0 zależy zarówno od umiejętności poruszania się w nowym środowisku osób odpowiadających za PR bibliotek, ale także od świadomości obecności biblioteki wśród użytkowników Internetu. Dbałość o relacje tworzone w sieci powinna uwzględniać potrzeby informacyjne użytkowników bibliotek oraz promocję ich działań w czasie rzeczywistym. Biblioteki uniwersyteckie doskonale wpasowały się w model działań PR 2.0, gdyż pamiętają o aktualizacji, różnych typach postów, multimediach, obserwacji ruchu, krótkim czasie odpowiedzi i znacznikach. Dzięki tym staraniom efektywnie prowadzony profil w serwisie społecznościowym stanowi ważny element strategii budowania marki biblioteki.

\section{Bibliografia}

Barefoot D., Szabo J., Znajomi na wage złota, Warszawa 2014.

Black S., Public Relations, Warszawa 1998.

Breakenridge D.K., PR 2.0: New Media, New Tools, New Audiences, New Jersey 2008.

Budkiewicz E., Mroczek R., Marketingowa rola wystaw - bibliotekarstwo aktywne, „Bibliotekarz” 1995, nr 11, s. 15-18.

Cenker E.M., Public relations, Poznań 2007.

Davis A., Public relations, Warszawa 2007.

Dudziak-Kowalska M., Internetowe strony $W W W$ bibliotek jako element public relations, „Biuletyn EBIB” 2004, nr 5, http:bib.oss.wroc.pl/2004/56/kowalska.php, [dostęp: 19.05.2017].

Fabjaniak-Czerniak K., Internetowe media społecznościowe jako narzędzie public relations, [w:] Zarzadzanie w sytuacjach kryzysowej niepewności, red. K. Kubiak, Warszawa 2012, s. 173-194.

Grzenkowicz S., Pierwsze kroki na Facebooku, [w:] Sunrise System, https://www.sun risesystem.pl/blog/2002-pierwsze-kroki-na-facebooku.html, [dostęp: 23.05.2017].

Hallingan B., Shah D., Inbound Marketing: daj się poznać w Google, serwisach spotecznościowych i na blogu, Gliwice 2010.

Huczek M., Public Relation a wizerunek biblioteki, „Biuletyn EBIB” 2004, nr 5, http:// ebib.oss.wroc.pl/2004/56/huczek.php, [dostęp 14.05. 2017]. 
Jaskowska B., Bądźmy tam, gdzie oni! Elementy social media marketingu w bibliotece, [w:] Bibliotekarze bez bibliotek, czyli bibliotekarstwo uczestniczace, Białystok 2012, s. 295-310.

Kaczmarek-Śliwińska M., Social media w działaniach internet PR przedsiębiorstw polskiego rynku, [w:] Public relations we wspótczesnym świecie: między stużbq organizacji i społeczeństwu, wybór i red. nauk. J. Olędzki, Warszawa 2011, s. $137-$ 154.

Kadragic A., Czarnowski P., Public Relations, czyli promocja reputacji, Warszawa 1997.

Kane G.C., Fichman R.G., Gallaugher J., Glaser J., Community relations 2.0, „Harvard Business Review" 2009, 01 Nov 87 (11): 45-50, 132.

Kai-Wah Chu S., Du H. S, Social networking tools for academic libraries, „Journal of Librarianship and Information Science" 2013, no 45 (1), s. 64-75.

Kotyśko M., Izdebski P., Michalak M., Andryszak P., Pluto-Prądzińska A., Nadmierne korzystanie z sieci spolecznościowych, „Alkoholizm i Narkomania” 2014, t. 27, nr 2, s. 177-197.

Krawulski J., Public Relations: wybrane zagadnienia, Poznań 2001.

Luo L., Wang Y., Han L., Marketing via social media: a case study, „Library Hi Tech” 2013, vol. 31, no 3, s. 455-466.

Mayer R., Jak wygrać każde negocjacje. nie podnoszac glosu, nie tracac zimnej krwi i nie wybuchając gniewem, Warszawa 2007.

Miotk A., Skuteczne social media. Prowadź dziatania, osiagaj zamierzone efekty, Gliwice 2013.

Oledzki J., Preambuła o PR między stużba organizacji i społeczeństwu, [w:] Public relations we wspótczesnym świecie: między stużba organizacji i spoteczeństwu, wybór i red. nauk. J. Olędzki, Warszawa 2011, s. 7-24.

Pokolenie XD - nowe pokolenie świadomych cyfrowo dzieci, „PC FORMAT”, https:// www.pcformat.pl/News-Pokolenie-XD----nowe-pokolenie-swiadomych-cyfrowo -dzieci,n,4881?utm_source=paste\&utm_medium=paste\&utm_campaign=firefox, [dostęp: 10.07.2017].

Public Relations, red. J. Olędzki, D. Tworzydło, Warszawa 2008.

Piontek D., Imagistyka spoleczna czy marketing polityczny, [w:] Media masowe w systemach demokratycznych, red. B. Dobek-Ostrowska, Wrocław 2003, s.100124.

Roguski A., Edge Rank dla zaawansowanych, [w:] Why so social?, [dostęp: 23.05.2017], http://www.whysosocial.pl/2014/11/edge-rank-dla-zaawansowanych .htmlhttp://www.whysosocial.pl/2014/11/edge-rank-dla-zaawansowanych.html.

Skerik S., Using Facebook for Public Relations, [w:] PR Newswire, [dostęp: 21.05.2017], http://www.prnewswire.com/blog/facebook-for-public-relations-19 04.html.

Solis B., Engage!: The Complete Guide for Brands and Businesses to Build, Cultivate, and Measure Success in the New Web, New York 2010. 
Solis B., The End of Business as Usual: Rewire the Way You Work to Succeed in the Consumer Revolution, New York 2011.

Special Report: Digital in 2017: Global Overview, [w:] Wearesocial.com, https:// wearesocial.com/special-reports/digital-in-2017-global-overview, [dostęp: 10.07. 2017].

Walecka-Rynduch A., Wideoideologia i youtubizacja jako narzędzia politycznego public relations, „Politeja” 2013, nr 25, s. 481-499.

Wanielista K., Miłkowska I., Słownik menadżera, Wrocław 1998.

Werenowska A., Jaska E., Nowoczesne narzędzia public relations $w$ ksztattowaniu wizerunku przedsiębiorstwa, [w:] Public relations - nie tylko Facebook, red. K. Stasiuk-Krajewska, Z. Chmielewski, D. Tworzydło, Rzeszów 2013, s. 169-179.

Wójcik K., Public Relation: od A do Z., Warszawa 2001. 